A more widespread understanding of biological principles will bring with it the realization that much more than tho prevention of genetic deterioration is to be sought for, and that the raising of the level of the average of the population nearly to that of the highest now existing in isolated individuals, in regard to physical wellbeing, intelligenco nnd temperamental qualities, is an achievement that would-so far as purely genetic considerations aro concerned-be physically possible within a comparatively small number of generations. Thus everyone might look upon 'genius', combined of course with stability, as his birthright. As the course of evolution shows, this would represent no final stago at all, but only an earnest of still further progress in the future.

The effectiveness of such progress, however, would demand incrcasingly extensive and intensive research in human genetics and in the numerous fields of investigation correlated therewith. This would involve the co-operation of specialists in various branches of medicine, psychology, chemistry and, not least, the socinl sciences, with the improvernent of the inner constitution of man himself as their central theme. The organization of the human body. is marvellously intricute, and the study of its genetics is beset with special difficulties which require the prosecution of research in this field to be on a much vaster scale, as well as more exact and analytical, than hitherto contemplated. This can, however, como about when men's minds are turned from war and hate and the struggle for the elementary means of subsistence to larger aims, pursued in common.

'Tho day when economic reconstruction will reach the stage where such human forces will be released is not yet., but it is the task of this generation to prepare for it, and all steps along the way will represent $a$ gain, not only for the possibilities of the ultimate genetic improvement of man, to a degreo seldom dreamed of hitherto, but at the same time, more directly, for human mastery over those more immediate evils which are so threatening our modern civilization.
F. A. F. Crew
G. P. Cinln
C.D. Darhington P. R. Davil)
J. B. S. Haldane G. Dahlbehg
P. C. Koller
IV. LANDAUER
S. C. Harland
Th. Dobzhanshy 13. I'rice
I. T. HogBex
R. A. Enkrsox
J. SCHU1,TZ
J. S. HUXLEY
C. Gordox
J. HAMmoND
II. J. MULLF:R
C. L. Huskiss
A.G.Steinber;
C. H. WAD- DINGTON

\title{
CONTACTS OF RELIGION AND SCIENCE
}

SIR RICHARD GREGORY, in choosing "Contacts $S$ of Religion and Science" ns the subject of his chairman's address prepared for the Division for the Social and International Relations of Science for the Dundeo meeting of the British Association, selected from the many topics of discussion open to him the one which, perhaps, most consistently holds the interest of thoso who are laymen in the double application of the term. He could have rendered no better service in both provinces of thought than he did by clarifying the issues, which in the popular mind aro so frequently, but as Sir Richard maintained, erroneously held to conflict.

At the very opening of his address Sir Richard mado his point of view clear when, after defining religion as "the reaction to an inner impulse as to what is conceived to be sacred and arouses awe or reverence", and science as "the accumulation of linowledge of the properties of natural objects-. animate and inanimate- in relation to man's needs and his understanding of them through the use of his intelligence", he went on to show that there can be no conflict between them when they aro conceived as joining in a higher unity, in which "all who are searching earnestly for truth, aro considered to be worshipping at the samo shrino". The dogmatisms of a few generations ago, both of men of science and theologians, are now giving way to a more liberal spirit. As ho said, "The study of science creates a feeling of infinite greatness in all who pursue it, and though it may lead to imperfect interpretation, its motive cannot be irreligious. . . . It is in the service of high ideals that science, without which we cannot live, and religion, without which most people see no meaning in life, can find a common field of action."

When Sir Richard had thus made clear his con. ception as a man of scienco of the relation between religion and science, ho proceeded in a brief historical survey to show what had been in fact the interactions of religion and science. Making special reference to the science of astronomy, he traced theso relations from their beginnings in primitive forms of society, through their development in the civilizations of IIesopotamia, Egypt, Indir, the cosmogonies of the Greeks, tho beginnings of modern scientific astronomical and physical knowledgo down to Darwinism and the development of the theory of evolution, "which placed man in a new relationship to the rest of living creatures".

In regard to evolutionary theory, or rather its mechanism, the struggle for existence, Sir Richard was at pains to point out the erroneous character of the view sometimes put forward that this is a striving after personal or national mastery at all costs-"a crude misconception repudiated alike by its founder, and by Huxley, its most powerful exponent, as contrary to the best ends of civilization". Further, man as "Nature's insurgent son", continually fighting against forces of evil which would destroy him, is yet able to survive by the use of his intelligence. "He may not know the reason for his existence, but he does know that thero is a law and order in thio natural world, and if he brealis them, the penalty is inevitable. Ifo has to oboy the lars of Nature in order to survive."

Iest the charge of materialism should be brough; against him for such doctrine, Sir Richard went on to show in effect that no brenk in the logical chain of argument, such as is sometimes imputed, is required to find a place for faith in such a view of Nature. For while "science is unable to provide any positive evidence for survival of personality after deaththat belief is a powerful ethical factor in human dovelopment. It is just as permissible, therefore, to assume that another world awaits habitation by an 
oxalted type of humanity after this earth has come to an end, as it is to believo in the eternal existenco of personality."

In conclusion, Sir Richard onco more omphasized the historical note. The attempts to find support for Christian belief in general, and the Mosaic account of Creation in particular, in naturalistic or rationalistic explanations, or those which aimed at fitting now knowledgo into a systern of thought having no claims to scientific accuracy, served no useful purposo to the Bible or to scienco. A much sounder basis was to be found in applying ovolutionary principles to religious thought and studying sacred books as stages in mnn's progressive discovery in theology. In science there aro no final interpretations or unchangeablo hypotheses; and when the samo principle is recognized in theology, religion will sharo somo of the vitality of the natural sciences. "It is through the acceptance of the idea of evolution in the spirit, as well as in the body of man, that tho partition which formerly separated religion and science is being dissolved."

\section{THE ANCESTORS OF THE EUTHERIA}

\section{By Dr. A. A. Abbie, Department of Anatomy, University of Sydney}

W

HA'IEVER may bo the opinions of individual investigators, or oven of groups of investi. gators, as to tho status of the ancestors of the eutherian mammals, there has not as yet appeared any conclusive ovidenco which can determine the issue in favour of any one of the several theories available. Dentition, placentation, details of the skeleton and other somatic characters havo all alike
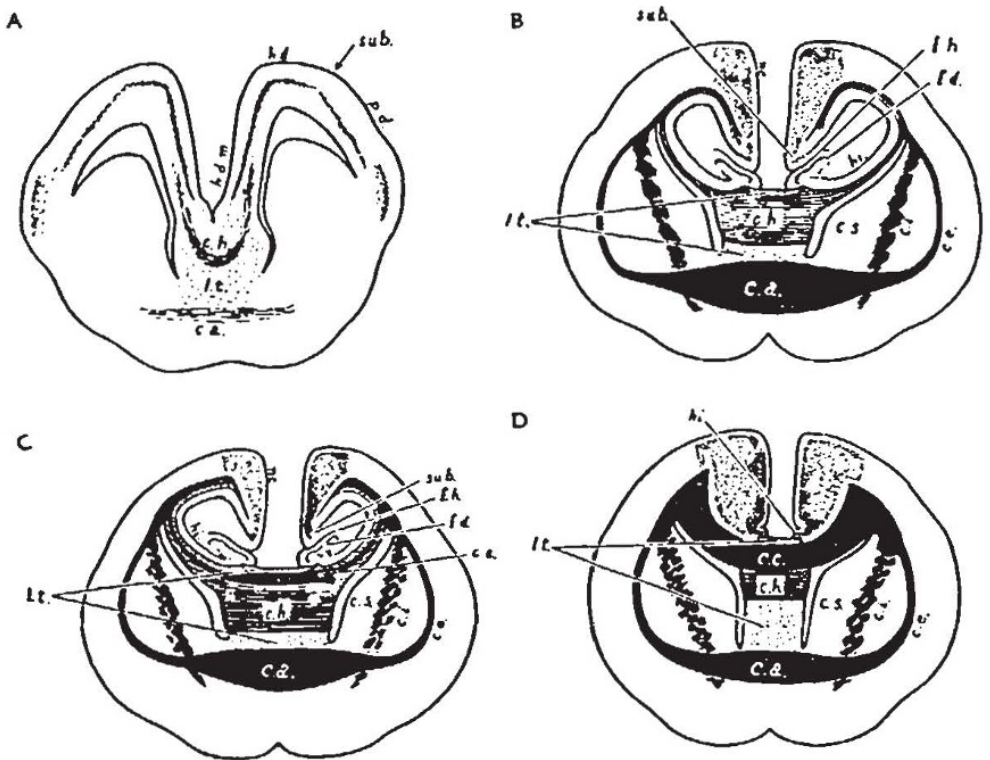

Fig. 1.

At the present moment any of these propositions could be advanced with little fcar of contradiction, although a general consensus of opinion would probably bo found to favour descent of the Eutheria from somo primitive, marsupial-like predecessor.

While bearing in mind Graham Kerr's caution against building too much upon the evidence of a single system, it may bo asserted, nevertheless, that

D

A, SECTION THROUGH THE HRAIN OF A REPTILE, TII.TQUA, to SHOW THY COMMISSURES ANI THF POSITION OF THE FASCIA DENTATA, HIPPOCAMPUS AND DORSAL PaLLIU⿴囗十

B, C, D, STAGes IN THE EVOLUTION OF THE CORPUS CALIOSUM ACCORDING TO Elliot SMITII: THE NEOCORTICAL FIRRES ARE SAID TO PASS THROVGI THE IIPPOCAMPAL COMMISSURE VENTRAL TO THE HIPPOCAMPUS. (For key to lettering, seo end of article).

failed to supply a decisivo solution to the problem. The ancestors may have been amphibians, reptiles, monotremes or marsupials ; the Eutheria may have been derived together with the Prototheria and tho Metatheria frorn a common ancestor; or the placentals may own one ancestor, the monotremes and marsupials another; or thoy may all have arisen independently from distinct pro-mammalian ancestors. in the brain there appears a structure-tho corpus callosum-which is peculiar to the Placentalin ${ }^{1,2,3}$, and that if the conditions essential to the formation of a corpus callosum could bo defined with sufficient procision, they would provide a guide to the structure of the brain in the ancestor of the Eutheria.

Elliot Smith presented tho viow that the corpus callosum is produced by infiltration of the dorsal part 